\title{
Comparative genomic characterization of citrus-associated Xylella fastidiosa strains
}

\author{
Vivian S da Silva ${ }^{1}$, Cláudio S Shida ${ }^{2}$, Fabiana B Rodrigues ${ }^{1}$, \\ Diógenes CD Ribeiro ${ }^{1}$, Alessandra A de Souza ${ }^{3}$, Helvécio D Coletta-Filho3, \\ Marcos A Machado ${ }^{3}$, Luiz R Nunes*1 and Regina Costa de Oliveira*1
}

\begin{abstract}
Address: ${ }^{1}$ Núcleo Integrado de Biotecnologia - Universidade de Mogi das Cruzes, Av. Dr. Cândido Xavier de Almeida Souza 200, Mogi das Cruzes, SP 08780-911, Brazil, ${ }^{2}$ Centro Interdisciplinar de Investigação Bioquímica - Universidade de Mogi das Cruzes, Av. Dr. Cândido Xavier de Almeida Souza 200, Mogi das Cruzes, SP 08780-911, Brazil and ${ }^{3}$ Centro APTA Citros Sylvio Moreira - Instituto Agronômico de Campinas, Caixa Postal 04, Cordeirópolis, SP 13490-970, Brazil

Email: Vivian S da Silva - schmidt@umc.br; Cláudio S Shida - shida@umc.br; Fabiana B Rodrigues - fa.biologa@yahoo.com.br; Diógenes CD Ribeiro - dicuri@gmail.com; Alessandra A de Souza - alessandra@centrodecitricultura.br; Helvécio D ColettaFilho - helvecio@centrodecitricultura.br; Marcos A Machado - marcos@centrodecitricultura.br; Luiz R Nunes* - Lnunes@umc.br; Regina Costa de Oliveira* - reginaco@umc.br

* Corresponding authors
\end{abstract}

Published: 21 December 2007

BMC Genomics 2007, 8:474 doi:10.1 186/1471-2164-8-474
Received: 3 August 2007

Accepted: 21 December 2007

This article is available from: http://www.biomedcentral.com//47I-2/64/8/474

(c) 2007 da Silva et al; licensee BioMed Central Ltd.

This is an Open Access article distributed under the terms of the Creative Commons Attribution License (http://creativecommons.org/licenses/by/2.0), which permits unrestricted use, distribution, and reproduction in any medium, provided the original work is properly cited.

\begin{abstract}
Background: The xylem-inhabiting bacterium Xylella fastidiosa $(X f)$ is the causal agent of Pierce's disease (PD) in vineyards and citrus variegated chlorosis (CVC) in orange trees. Both of these economically-devastating diseases are caused by distinct strains of this complex group of microorganisms, which has motivated researchers to conduct extensive genomic sequencing projects with $X f$ strains. This sequence information, along with other molecular tools, have been used to estimate the evolutionary history of the group and provide clues to understand the capacity of $X f$ to infect different hosts, causing a variety of symptoms. Nonetheless, although significant amounts of information have been generated from $X f$ strains, a large proportion of these efforts has concentrated on the study of North American strains, limiting our understanding about the genomic composition of South American strains - which is particularly important for CVC-associated strains.

Results: This paper describes the first genome-wide comparison among South American $X f$ strains, involving 6 distinct citrus-associated bacteria. Comparative analyses performed through a microarray-based approach allowed identification and characterization of large mobile genetic elements that seem to be exclusive to South American strains. Moreover, a large-scale sequencing effort, based on Suppressive Subtraction Hybridization (SSH), identified 290 new ORFs, distributed in 135 Groups of Orthologous Elements, throughout the genomes of these bacteria.

Conclusion: Results from microarray-based comparisons provide further evidence concerning activity of horizontally transferred elements, reinforcing their importance as major mediators in the evolution of Xf. Moreover, the microarraybased genomic profiles showed similarity between $X f$ strains $9 a 5 c$ and $F b 7$, which is unexpected, given the geographical and chronological differences associated with the isolation of these microorganisms. The newly identified ORFs, obtained by SSH, represent an approximately 10\% increase in our current knowledge of the South American Xf gene pool and include new putative virulence factors, as well as novel potential markers for strain identification. Surprisingly, this list of novel elements include sequences previously believed to be unique to North American strains, pointing to the necessity of revising the list of specific markers that may be used for identification of distinct $X f$ strains.
\end{abstract}




\section{Background}

The xylem-inhabiting bacterium Xylella fastidiosa (Xf) $[1,2]$ has emerged, during the past decades, as an important phytopathogen, specially due to its implication with the development of Pierce's disease (PD) in North American vineyards and citrus variegated chlorosis (CVC), which affects orange trees in South America. PD was first detected in Southern California in 1884, when it destroyed approximately 40,000 acres of grapes in Anaheim, CA, during a 5-year outbreak of the disease (reviewed in [3]). After this devastating experience, PD remained as a minor concern to the West Coast viticulture for decades until the mid-1990s, when a new insect species, the glassy-winged sharpshooter (GWSS) Homalodisca vitripennis was accidentally introduced into Southern California and begun spreading northward. This leafhopper, which can serve as a vector to $X f$, has the capacity to feed in more than 70 different plant species and survive winter temperatures dropping as low as $20^{\circ} \mathrm{F}$ [4]. Moreover, unlike other $X f$-carrying insects associated with PD in California, GWSS has a much broader flight range (up to a quarter mile), posing a very serious threat to the wine industry from Southern and Central California [5]. Indeed, since the first identification of GWSS in the California vineyards, programs aimed at controlling the dissemination of this insect as a strategy to prevent PD outbreaks have involved more than US $\$ 160$ million of direct investments [6].

Citrus variegated chlorosis, on the other hand, was originally identified in Brazil in 1987, during an outbreak that affected orange orchards distributed along the Northern and Northwestern regions of State of São Paulo [7], one of the most important areas of citrus production in this country, which turns out to be one of the world's leading producers of concentrated orange juice (reviewed in [8]). Since its initial observation, the disease incidence increased by graft propagation of $X f$-infected budwood and by the action of many different sharpshooter vectors, becoming widely distributed across all citrus-growing regions in the country, where it is held responsible for damages that may reach US\$280 - 320 million per year [9] (see also [10] for recent statistics about CVC in Brazil).

Different $X f$ strains have also been obtained from alternative host plants across the Americas and, in many cases, there seems to be a direct correlation between $X f$ infection and the development of diseases [11]. Thus, $X f$ strains are also believed to be responsible for phony peach disease (PP), alfalfa dwarf disease, periwinkle wilt and leaf scorch diseases in plum, elm, maple, oak, sycamore and coffee $[12,13]$. Up to now, none of these diseases has demonstrated to be as economically damaging as either PD or CVC. Nonetheless, $X f$ is already considered a major agronomical concern in the American continent, given the economic losses already experienced by both citrus and winegrape industries, as well as the widespread distribution of $X f$ strains in so many economically important crops. Thus, this microorganism has been the subject of increasing attention by many research programs after the mid 1990's [14] and, as a consequence of these efforts, one Xf strain (9a5c), associated with CVC in Brazil, turned out to be the first plant bacterium to have its complete genome sequenced and annotated [15]. Moreover, the existence of different disease symptoms, observed in a wide range of plant hosts [16] and associated with genetically distinct $X f$ strains, has led researchers to hypothesize that total genome comparisons among these bacteria could help to uncover information regarding genes involved in the interaction with specific hosts and disease development [17]. Thus, sequencing efforts have been extended to other $X f$ strains and subsequently, the genomes of two other strains (Ann-1 and Dixon), obtained from oleander and almond trees had their genomes partially sequenced and annotated [18]. Finally, a fourth strain, Temecula-1, isolated from grapevines and responsible for PD in California has also been sequenced to completion [19]. Thus, $X f$ is one of the best models available to conduct functional and comparative genomic studies.

Genomic sequences from these $X f$ strains have been submitted to extensive in silico evaluations, allowing the formulation of virtual metabolomes that provided a comprehensive view of the major biochemical processes that occur in these microorganisms [15]. Additional information regarding the functionality of different gene products and pathogenicity mechanisms in $X f$ have also been obtained by the evaluation of differential gene expression through microarray hybridization approaches and by the generation of gene-knockout mutants $[20,21]$, while genomic comparisons conducted with these four strains allowed the identification and categorization of genomewide DNA variations, as well as their influence on strain functional divergence [22]. Multiple alignment of chromosomal sequences identified SNPs and INDELs that could be used to estimate the relative similarity between the strains and the rates of genome evolution, which seem to be different for each individual strain [22]. All unique genes have been catalogued and, since their sequences could represent strain-specific markers, primer pairs were designed against these ORFs to assist in PCR-based detection of these four $X f$ strains in the wild $[22,23]$.

The genomic information also established a solid base for the development of epidemiological and phylogenetic studies within the $X f$ group, providing evidence that the bacterial species $X$. fastidios $a$, originally characterized from 25 strains (obtained from 10 different hosts), constitute a significantly complex group of plant-associated bacteria 
[14]. In spite of sharing a considerable amount of both phenotypic and genotypic similarities, as well as an overall $85 \%$ DNA sequence identity, as measured from DNA homology studies [2], X. fastidiosa strains and strains have been shown to display significant biological variability, which was confirmed by phylogenetic analyses involving sequence comparison of seven chromosomal genes (spanning almost $10 \mathrm{~Kb}$ of DNA sequence), sequencing of the ribosomal intergenic spacer (ITS), serological classification and microarray analyses of their genomic profiles [14,24-27].

However, all these studies involved a relatively small number of South American $X f$ strains, hampering a more conclusive evaluation about the biogeographical distribution, phylogenetic history, evolution and taxonomic relationships among this group of strains, which have not been as thoroughly studied as the North American strains. A similar situation is verified when $X f$ strains are analyzed and compared at the genomic level, since three North American strains have been submitted to genomic sequencing, as opposed to only one South American strain. Thus, it is possible that the relative lack of sequence information from other South American strains may have introduced biases to some of the conclusions drawn from recent genomic studies within the group. This situation prompted us to conduct a comprehensive genomic survey involving a total of 6 South American $X f$ strains, all obtained from infected orange trees [28]. We employed a microarray-based approach to compare the genomic profiles of these bacteria with $X f$ strain $9 \mathrm{a} 5 \mathrm{c}$ and Suppressive Subtraction Hybridization (SSH) to identify new genes present exclusively in the genomes of these microorganisms. The results obtained from such analyses represent the first genome-wide evaluation regarding genome structure and composition from CVC-associated bacteria, providing additional information about the characteristics of the South American $X f$ gene pool and its relationship with what has been found in North American strains.

\section{Results}

Genomic comparisons among Xf-CVC strains through microarray hybridization analysis

Microarray hybridization has been widely used to undertake genomic comparisons involving a great number of microorganisms [29] and previous work from our group has established precise criteria to employ this methodology to the study of $X f$ strains, with the aid of an $X f 9 \mathrm{a} 5 \mathrm{c}$ biochip [30]. Thus, we performed similar microarraybased comparisons with 6 different $X f$ strains obtained from citrus plants (Table 1). Four of these $X f$ strains (56a, 9.12c, 187b, and 36f) were obtained from CVC-affected trees and are representatives of the most prevalent $X f$ haplotypes found in sweet orange orchards across the state of São Paulo, while $X f$ strain Cv21 was obtained from a nonsymptomatic tree from the same region [28]. Xf strain $\mathrm{Fb} 7$, on the other hand, was obtained from a sweet orange tree that displayed symptoms of "Pecosita", a disease similar to CVC that occurs in some citrus-growing regions of Argentina [31]. The genomic profiles obtained for these 6 strains are depicted in Figure 1, which displays a linear representation of the $X f$ strain $9 a 5 c$ chromosome (from ORF Xf0001 to Xf2782), followed by ORFs present in $\mathrm{p} X f 51$, the large $51 \mathrm{~kb}$ chromosome present in $X f$ strain $9 \mathrm{a} 5 \mathrm{c}$ (from ORF $X f \mathrm{a} 0001$ to $X f a 0064$ ). Surprisingly, these results showed that, contrary to what had been observed during our former comparisons [26], most genomic differences within the citrus strains are not associated with deleted ORFs, but with elements that are present in greater copy number in the tested strains, when compared to $X f$ strain 9a5c (see Table 2, and Additional File 1). Nonetheless, we were able to confirm the same distribution pattern observed before, since most duplicated ORFs are not scattered throughout the genome, but grouped within mobile genetic elements, such as prophages, Genomic Islands (GIs) and putative Genomic Islands (pGIs) previously observed in the genome of $X f$ strain $9 \mathrm{a} 5 \mathrm{c}$ [26].

Details regarding differences in ORF composition, detected by the microarray hybridizations with all $\mathrm{Xf}$ strains analyzed in this study, can be found in Additional File 1. As expected, each strain presents a unique genomic profile, which can be used to characterize all individual strains with high fidelity, as inferred from the high bootstrap values obtained from the cluster analysis shown in Figure 1. Interestingly, the Argentine strain, Fb7, seems to be extremely similar to Xf strain $9 \mathrm{a} 5 \mathrm{c}$, as the genomic differences detected between these two strains are restricted to a small number of deleted ORFs, distributed along the main chromosome and plasmid pXf51. All other strains

Table I: Xylella fastidiosa (Xf) strains used in this study.

\begin{tabular}{lll}
\hline$X f$ Strain & Host & Geographical Origin \\
\hline $9.12 \mathrm{c}$ & Citrus sinensis cv. Pera & Gavião Peixoto, SP - Brazil \\
$56 \mathrm{a}$ & Citrus sinensis cv. Sanguinelli & Ubarana, SP - Brazil \\
$187 \mathrm{~b}$ & Citrus sinensis cv. Valência & Ubarana, SP - Brazil \\
$36 \mathrm{f}$ & Citrus sinensis cv. Matidije Navel & Ubarana, SP - Brazil \\
$\mathrm{Cv21}$ & Citrus sinensis & Colina, SP - Brazil \\
$\mathrm{Fb7}$ & Citrus sinensis cv. Valencia & Bella Vista, Corrientes - Argentina \\
\end{tabular}




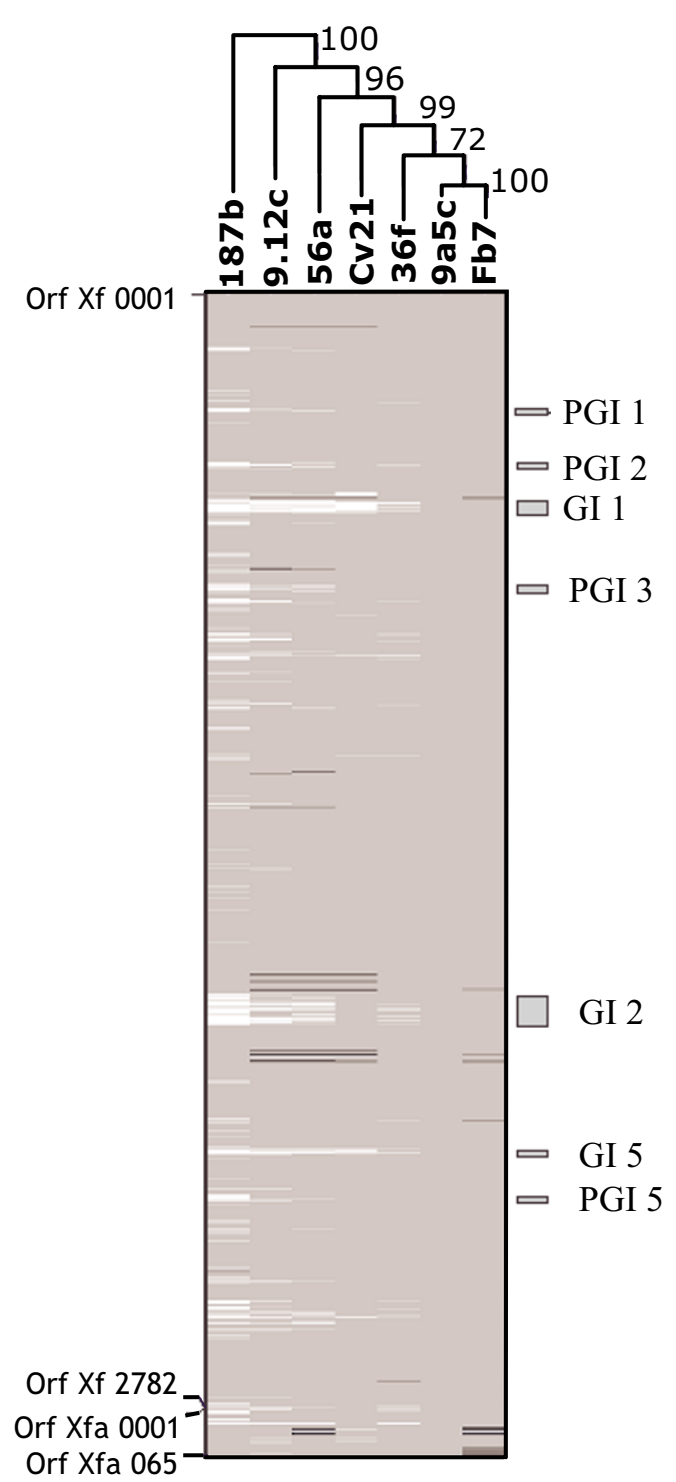

Figure I

Genomic comparison of citrus-associated Xylella fastidiosa $(X f)$ strains by microarray hybridization showing the distribution of ORFs with reference to the genome of $X f$ strain $9 a 5 c$. Chromosomal ORFs are linearly represented, from ORF $X f 0001$ to ORF $X f 2782$, followed by ORFs from plasmid $\mathrm{p} X f$ 5.I (from ORF $X f a 000 I$ to $X f a 0065$ ). ORFs present in the genome of each tested strain are represented in grey, while missing ORFs are represented in black. ORFs present in greater copy number in the genomes of the tested strains are represented in white [see 26]. The genomic profiles were used to construct a hierarchical grouping of the strains and the robustness of the branching profile was verified by bootstrap analysis, using TMEV (the number next to each branch represents the bootstrap values for 100 permutations). The location of Genomic Islands (Gls) and putative Genomic Islands ( $p G I s)$ in the genome of $X f$ strain $9 \mathrm{a} 5 \mathrm{c}$ are also shown [see 26]. display significantly different profiles, characterized not only by deletions, but also by duplicated ORFs. A strong similarity is observed in the profiles obtained for Xf strains 56 a and $9.12 c$, characterized by scattered duplication of ORFs from GI2, and by what seems to be complete duplications of GI1 and GI5. Several ORFs from prophage XfP4 and GI4 are also missing in these two strains. Xf strain Cv21 presents a genomic profile that closely resembles Xf strains 56a and 9.12c, except for the lack of duplications involving ORFs within GI2. Xf strain 36f, on the other hand, displays another type of profile, in which no deletions have been detected along the structures of XfP4 and GI4 and the duplicated ORFs scattered across GI1 and GI5 seem to indicate that duplication of these elements is not complete. Finally, Xf strain 187b displays the most divergent genomic profile, characterized by a very large number of duplicated ORFs and mobile elements. Once again, duplications seem to span practically the entire structure of GI1, GI5 and even GI2. Moreover, several other duplicated regions seem to occur throughout the genome of Xf strain $187 \mathrm{~b}$, pointing to the possible existence of other mobile genetic elements in Xf. Interestingly, at least three of these regions seem to map within elements that had been previously identified as putative Genomic Islands (pGIs) [26].

The two largest $X f$ GIs (GI1 and GI2), which were found to be deleted in North American strains are present in all citrus strains analyzed herein and GI1 seems to be completely duplicated in at least four of the tested $X f$ strains (187b, 56a, 9.12c and Cv21), as well as in two previously analyzed citrus $X f$ strains, X1-B14 and SJ [26], indicating that this element seems to display intense transpositional activity among representatives of the $X f$ group. Interestingly, GI1 seems to be specific to strains obtained from citrus and coffee trees from South America and may represent a sinapomorphy for the South American $X f$ strains [26]. GI5, which is also duplicated in other $X f$ strains (56a and 9.12c), displays a region that is similar to the VapE-containing region of GI1, resembling the situation observed with the Vap elements from the pathogenic bacterium Dichelobacter nodosus (see below [32]).

\section{Identification of new ORFs in the Xf-CVC gene pool of citrus-associated Xf strains through Suppressive Subtraction Hybridization (SSH)}

Since the $X f$ biochip used in the experiments described above was based on the genome of $X f$ strain $9 a 5 c$, the hybridization experiments can only provide information regarding genes that are present in this strain. Thus, to gather information concerning additional ORFs present in the gene pool of citrus-associated strains, we employed Suppressive Subtraction Hybridization (SSH), using DNA from $X f$ strain $9 \mathrm{a} 5 \mathrm{c}$ as a driver, against DNA from all 6 strains, as described in Methods. Thus, a total of $18 \mathrm{SSH}$ 
Table 2: Number of ORFs found to be deleted or present in higher copy number in the strains analyzed in this study, using as a reference the genome of Xylella fastidiosa strain $9 \mathrm{a} 5 \mathrm{c}$. A complete list of such ORFs is available online as Additional File I

\begin{tabular}{|c|c|c|c|c|c|c|}
\hline & $187 b$ & $36 f$ & $56 a$ & $9.12 c$ & Cv2I & $\mathrm{Fb7}$ \\
\hline Number of ORFs present in higher copy number in the genomes of the strains used in this study & 337 & 46 & 92 & 129 & 49 & 00 \\
\hline Number of ORFs found to be deleted in the genomes of the strains used in this study & 00 & 01 & 26 & 19 & 15 & 27 \\
\hline
\end{tabular}

libraries have been constructed (using three different restriction enzymes for each strain) and approximately 9,000 clones have been obtained and sequenced from these libraries (Table 3).

For each of the 6 strains, the sequenced clones have been trimmed, in order to exclude vector sequences and poor quality regions (Phred $<20$ ), and aligned with the aid of CAP3, generating 1,063 contigs, which contained 6,712 sequences overall. These contigs span $217.1 \mathrm{~Kb}$ of $\mathrm{Xf}$ sequences, which is equivalent to approximately $7.7 \%$ of the genome of $X f$ strain 9a5c (Table 4). We chose to conduct further analyses only with contigs composed by at least 6 different individual sequences and showed size variation from 400 to $4,500 \mathrm{bp}$. Thus, a total of 2,534 sequenced clones were excluded from further studies, since they either remained as singlets or grouped into small contigs, composed by a limited number of reads ( 2 in most cases), resulting in poor quality consensus sequences. Next, the contigs were filtered against the genome of $X f$ strain $9 \mathrm{a} 5 \mathrm{c}$ with the aid of the software cross_match [33], allowing the identification of stretches of DNA that were exclusive to the tested strains. Sequencing of approximately 9,000 SSH clones has allowed the identification of $111.53 \mathrm{~Kb}$ of DNA sequences that are not present in the genome of $X f$ strain $9 \mathrm{a} 5 \mathrm{c}$ (which represents $\sim 4.1 \%$ of total genome size). The rate at which novel sequences were identified, as a function of sequenced SSH clones, has been evaluated as described in Methods, and judging by the inclination of the curve shown in Figure 2, a significant proportion of the novel sequences present in the analyzed genomes is likely to have been identified in this study. These newly identified sequences were analyzed with GeneMark [34], to search for individual elements present in their structure, allowing the

Table 3: Number of SSH clones obtained and sequenced for each Xylella fastidiosa $(X f)$ strain

\begin{tabular}{cccc}
\hline Xf Strain & \multicolumn{3}{l}{ Restriction enzyme used in the SSH reactions } \\
\cline { 2 - 4 } & Rsa I & Alu I & Dra I \\
187b & 1.344 & 384 & 384 \\
Cv21 & 688 & 160 & 288 \\
$56 \mathrm{a}$ & 480 & 140 & 124 \\
$9.12 \mathrm{c}$ & 958 & 704 & 424 \\
$36 \mathrm{f}$ & 960 & 720 & 192 \\
Fb7 & 864 & 144 & 288 \\
\hline
\end{tabular}

identification of 290 new ORFs, scattered throughout the genomes of the 6 strains analyzed herein (see GenBank accession numbers ER935541 to ER935830). This represents an increment of approximately $10.2 \%$ in the number of ORFs currently known to belong to the gene pool of citrus-associated $X f$ [15].

However, comparative analyses among these 290 newly identified ORFs has shown that a large proportion of these elements (228 ORFs) seemed to belong to different groups of orthologous proteins, present in the genomes of two or more tested strains. Thus, to reduce the redundancy of this dataset, the predicted protein sequences from these 290 ORFs have been submitted to cluster analysis, as described in Methods, resulting in 135 Groups of Orthologous Elements (GOEs), which are more likely to represent the actual number of new functional genes identified in the gene pool of the tested $X f$ strains (see Additional File 2). Analyses of similarity against the GenBank have then been performed with Blastx, using the consensus sequences from each GOE as input, which allowed the assignment of putative functions for each of these newly identified elements. Their distribution into the different functional categories originally described by Simpson and co-workers is shown in Figure 3[15]. Surprisingly, a relatively small proportion of such sequences has been identified as "no hit" (only 23, which is equivalent to $17 \%$ of the newly identified GOEs). Another large fraction of elements (37) has been identified as conserved hypothetical proteins ( $\sim 28 \%$ of the total), displaying high similarity to ORFs of unknown function, previously identified in the genomes of other microorganisms - particularly in other $X f$ strains (see below). Putative functions could be attributed to 75 newly identified GOEs ( $55 \%)$ and the majority of them (50) are directly associated with mobile genetic elements, since we identified 2 new phage structural proteins, 8 recombinases/integrases, 14 elements involved with plasmid replication/stabilization and 26 elements that are homologous to conjugation factors belonging to the $\mathrm{TraA} / \mathrm{TraB} / \mathrm{Cag} / \mathrm{Vir}$ families, originally described in Agrobacterium tumafasciens [35]. The remaining 25 GOEs, (18.5\%) encode proteins that are involved with several metabolic processes of the cell, including a group of six new potential virulence factors, which had not been originally identified in the genome of $X f$ strain $9 \mathrm{a} 5 \mathrm{c}$. These include two homologues for the transcription factor AbrB (GOEs \#17 and \#43 in Additional File 1), a 
Table 4: Number and size of contigs obtained for each Xylella fastidiosa $(X f)$ strain

\begin{tabular}{|c|c|c|c|c|c|c|c|}
\hline Xf Strain & $\mathrm{Cv} 21$ & $187 b$ & $56 a$ & $\mathrm{Fb7}$ & $9.12 c$ & $36 f$ & Total \\
\hline Number of contigs assembled by CAP3 & 97 & 393 & 58 & 125 & 208 & 182 & 1063 \\
\hline Overall number of base pairs in the assembled contigs (in $\mathrm{Kb}$ ) & 37.7 & 40.7 & 29.9 & 31 & 52.8 & 25 & 217.1 \\
\hline
\end{tabular}

new pilin gene (GOE \#76 in Additional File 1), two Lpx acetyltransferases (GOE \#26 and \#93 in Additional File 1) and a gene encoding the Zonula Ocludens Toxin (Zot) from Vibrio cholerae (GOE \#51 in Additional File 1).

The Blastx analyses also confirmed that the sequences from all 135 elements described above could not be found in the genome of $X f$ strain 9a5c. Surprisingly, however, these analyses showed that a large proportion of these sequences $(67.5 \%)$ has already been identified in $X f$ strains from North America - particularly in the case of $X f$ Ann-1, isolated from oleander (Figure 4). As shown in Additional File 3, the consensus sequences from 67 GOEs, showed high similarity to ORFs originally described in $X f$ strain Ann-1, encoding both hypothetical proteins and proteins with assigned functions. Sixteen GOEs showed

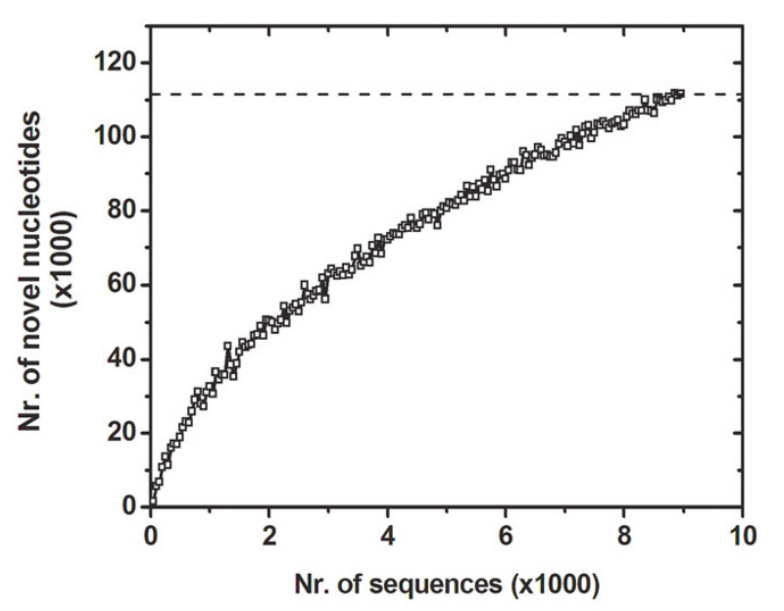

Figure 2

Redundancy analysis of the SSH experiments. To verify the effectiveness of the $\mathrm{SSH}$ sequencing approach to continually identify novel sequences in the genomes of the $X f$ strains in this study, increasing numbers of $\mathrm{SSH}$ sequences were submitted to clustering analyses with Phred/CAP3 and the consensus sequences obtained through this analysis were filtered against the genomic sequence of $X f$ strain $9 a 5 c$. The number of novel nucleotides identified through this approach was plotted as a function of sequenced SSH clones. The inclination of the curve indicates that the SSH approach is still capable of identifying novel sequences in the genomes of the tested strains, although it is likely that most such sequences have already been obtained. high similarity with elements identified in the genome of $X f$ strain Dixon (isolated from almond trees) and eight were most similar to sequences found in $X f$ strain Temecula-1 (isolated from grapevines). Such an overlap with genes from the North American $X f$ gene pool was unexpected and suggests that the list of unique ORFs, recently proposed by Doddapaneni and coworkers [22], as potential targets for strain-specific detection of North American $X f$ strains in the wild must be revised [36]. As shown in Table 5, approximately $27.7 \%$ of the ORFs, previously believed to be unique to $X f$ strain Ann-1 (23 out of 83) and $5.5 \%$ of the ORFs, previously believed to be unique to $X f$ strain Dixon (3 out of 54) have also been found in the citrus-associated strains analyzed in this study. On the other hand, since the consensus sequences from 23 GOEs returned "no hit" when compared to the NCBI databases, these elements might prove useful as targets for PCRbased detection of citrus-associated $X f$ strains (Figure 3 ).

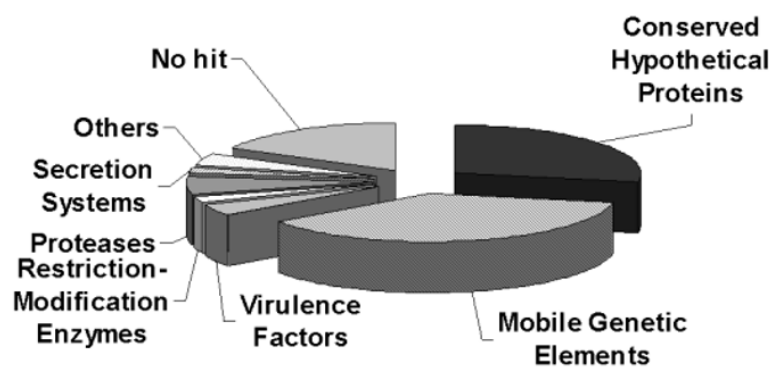

\section{Figure 3}

Functional distribution of the 135 Groups of Orthologous Elements (GOEs) that have been identified in the genomes of these strains through SSH analysis. These sequences were obtained after alignment of sequenced $\mathrm{SSH}$ clones from each strain. The consensus sequences for each contig were filtered against the genome of $X f$ strain $9 \mathrm{a} 5 \mathrm{c}$ and the remaining sequences were analyzed with GeneMark to identify new ORFs. The sequences from such ORFs have been clustered and the resulting contig consensuses (or singlet sequences) have been submitted to Blastx analyses against the GenBank. Functional classification was done according to Simpson and coworkers [I5]. 


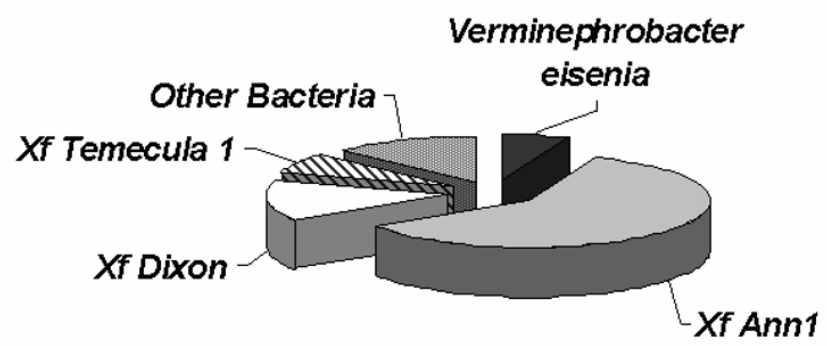

\section{Figure 4}

Identification of the microorganisms carrying the closest homologue for each of the 135 Groups of Orthologous Elements (GOEs) that have been identified in the genomes of the tested strains through $\mathrm{SSH}$ analysis. These sequences were obtained after alignment of sequenced $\mathrm{SSH}$ clones from each strain. The consensus sequences for each contig have been filtered against the genome of $X f$ strain $9 a 5 c$ and the remaining sequences were analyzed with Genemark to identify new ORFs. The sequences from such ORFs have been clustered and the resulting contig consensuses (or singlet sequences) have been submitted to Blastx analyses against the GenBank. The most significant Blast hit was considered for this analysis.

Altogether, the consensus sequences from only 21 GOEs showed similarity to genes identified in microorganisms that do not belong to the Xf group (Figure 4). Interestingly, one third of these elements (7) seem to be homologous to ORFs identified in the genome of Verminephrobacter eiseniae, a soil-inhabiting bacterium that infects nematodes [37], while the remaining ones show high similarity to genes found in a great number of microorganisms, such as E. coli, Geobacter metalireducens, Salmonella enterica, Solibacter usitatus, Xanthomonas sp., Burkholderia sp., Chlorobium tepidum, among others.

\section{Discussion}

Results obtained from several lines of research, developed during the past decade, have turned the phytobacterium Xylella fastidiosa into a unique model of study in the fields of both phytopathology and genomics. First of all, this is due to the fact that several diseases, associated with many distinct bacterial strains have been characterized and some of these diseases are responsible for significant economic losses. Moreover, a significant amount of genomic information has been obtained for four different strains of this microorganism, allowing the development of both functional and comparative genomic analyses within the group. Comparisons performed with the four sequenced $X f$ genomes led Doddapaneni and coworkers to suggest that the Tenecula-1 strain genome is the one that most likely resembles the ancestral $X f$ genome, since it has undergone the fewest genetic changes among the four analyzed strains [22]. Thus, $X f$ strain 9a5c (as well as other South American strains) may have evolved from an ancestral bacterium, carrying a Temecula-1-like genome, through incorporation of a series of horizontally transferred elements, such as prophages, GIs and plasmids [26]. This possibility is reinforced by the microarray-based comparisons undertaken in this study with the citrusassociated strains, since they provide further evidence for intense transpositional activity of mobile elements during the evolution of this subgroup of $X f$.

So far, most comparative studies among South American $X f$ strains have essentially involved Brazilian strains from both citrus and coffee trees. In general, the available data supports the idea that CVC-associated bacteria found in Brazil have evolved directly from $X f$ strains that cause coffee leaf scorch (CLS), since CVC-associated $X f$ strains have been shown to induce CLS symptoms when experimentally inoculated into coffee trees [38]. Moreover, it is widely known that most areas in which citrus orchards are presently cultivated used to be dedicated to coffee plantations and there have been reports of CVC vectors feeding on coffee trees [39]. Nonetheless, the exact origin of CVCrelated $X f$ strains is still a matter of speculation, since very little research has been performed on Pecosita-related $X f$ strains. The origin of this subgroup of $X f$ is an important piece of information regarding the evolutionary history of citrus-associated $X f$ strains, specially considering that Pecosita has been known to occur in Argentina before the first descriptions of CVC in Brazil (reviewed in [31]).

Thus, the present study shows the first genomic-scale comparative evaluation involving a Pecosita-related $X f$ strain (Fb7). It is interesting to verify from these data that, while $X f$ strain Fb7 (isolated in 2000) appears to be very similar to $X f$ strain 9a5c (isolated back in 1987 [7]), significant genomic differences have been observed when these strains are compared to Xf-CVC bacteria isolated in more recent years, specially regarding the activity of horizontally transferred elements. Although it is tempting to speculate from this data that the evolutionary rates among CVC- and Pecosita-related strains might differ, it is clear that further phylogenetic and biogeographical studies have yet to be performed in order to shed more light into our knowledge regarding the evolutionary history of the South American $X f$ strains, as well as their corresponding diseases. An attempt to verify the evolutionary relationships between $X f$ strains $9 \mathrm{a} 5 \mathrm{c}, \mathrm{Fb} 7$ and the other $X f$ strains has been performed by sequencing the 16S-23S rDNA spacer region of these bacteria, but since no strain-specific mutations have been found in this sequence, such analysis turned out to be inconclusive (data not shown).

As mentioned before, the fact that the overall genomic information obtained for $X$. fastidiosa has been mostly 
Table 5: List of ORFs originally identified as specific for the North American Xylella fastidiosa (Xf) strains Ann-I and Dixon, whose sequences have been found in the genomes of the $X f$ strains used in this study. The presence of sequences related to each ORF in the genomes of the strains analyzed by us is marked by an $X$.

\begin{tabular}{|c|c|c|c|c|c|c|c|c|}
\hline ORFa & Identified in this study as & Putative function & $187 b$ & $56 a$ & $9.12 \mathrm{c}$ & Cv2l & $\mathrm{Fb7}$ & $36 f$ \\
\hline Ann FY0I84 & GOE \#I7 & Transcriptional regulator AbrB & $\mathrm{x}$ & $\mathrm{x}$ & & & $x$ & \\
\hline Ann FY0I85 & GOE \#127 & Conserved hypothetical protein & & & & $\mathrm{x}$ & & \\
\hline Ann FY0934 & GOE \#19 & Putative transposase TnA & $x$ & $x$ & & & & \\
\hline Ann FY0977 & GOE \#133 & Conjugation Trbl-like protein & & & & $x$ & & \\
\hline Ann FY0978 & GOE \#23 & Conserved hypothetical protein & $\mathrm{x}$ & & $x$ & & & \\
\hline Ann FY0979 & GOE \#16 & Resolvase, N-terminal:Resolvase helix-turn-helix region & & $\mathrm{X}$ & & $x$ & & \\
\hline Ann FY0983 & GOE \#20 & Helix-turn-helix motif & $x$ & $x$ & $x$ & $x$ & & \\
\hline Ann FY0984 & GOE \#42 & Conjugal transfer protein TrbG/VirB9/CagX & & $x$ & $x$ & $x$ & & \\
\hline Ann FY0985 & GOE \#52 & Conserved hypothetical protein & $x$ & $\mathrm{x}$ & & $x$ & & \\
\hline Ann FY0988 & GOE \#30 & VirB8 & $x$ & $x$ & & $x$ & & \\
\hline Ann FY0989 & GOE \#02 & TrbL/VirB6 plasmid conjugal transfer protein & $x$ & $x$ & $x$ & $x$ & & $x$ \\
\hline Ann FY0992 & GOE \#63 & Plasmid-related exported protein & & & & $x$ & & $x$ \\
\hline Ann FY0993 & GOE \#26 & Transferase hexapeptide repeat & $x$ & & $x$ & $x$ & & \\
\hline Ann FY0996 & GOE \#07 & Probable conjugal transfer protein TraL & $x$ & $x$ & $x$ & & & $x$ \\
\hline Ann FY0997 & GOE \#59 & Conserved hypothetical protein & & $\mathrm{x}$ & $x$ & $x$ & & $x$ \\
\hline Ann FYI07I & GOE \#56 & Conserved hypothetical protein & $x$ & $\mathrm{x}$ & $x$ & $x$ & $x$ & $x$ \\
\hline Ann FY2430 & GOE \#68 & Conserved hypothetical protein & & & $x$ & $x$ & & \\
\hline Ann FY2499 & GOE \#62 & Conserved hypothetical protein & & & $x$ & & & $x$ \\
\hline Ann FY25I3 & GOE \#II6 & Helix-turn-helix motif:Peptidase S24, S26A and S26B & $x$ & & & & & \\
\hline Ann FY2526 & GOE \#3I & type IV secretory pathway, VirB3 family protein & & $\mathrm{x}$ & $x$ & $x$ & & \\
\hline Ann FY2545 & GOE \#12 & Conserved hypothetical protein & & & $x$ & $x$ & & \\
\hline Ann FY2555 & GOE \#70 & Conserved hypothetical protein & & & & $x$ & & $x$ \\
\hline Ann FY35I0 & GOE \#43 & SpoVT/AbrB-like & & $\mathrm{X}$ & $\mathrm{x}$ & & & \\
\hline Dixon FX034I & GOE \#7I & Helix-turn-helix motif: Peptidase S24, S26A and S26B & & & $x$ & $x$ & & \\
\hline Dixon FX2654 & GOE \#107 & Putative plasmid conjugal transfer protein TraJ & & & & & $x$ & \\
\hline Dixon FX3105 & GOE \#96 & Conserved hypothetical protein & & & & & $x$ & \\
\hline
\end{tabular}

a As described by Doddapaneni and coworkers [22].

based on sequence information derived from North American strains, was likely to have biased to some of the conclusions obtained so far, specially considering the evolutionary complexity of these bacteria, which have been shown to carry an extremely large and active flexible gene pool [26]. As expected, the SSH experiments described in this work, which constitute the first attempt to undertake a large-scale survey of the genomic composition of South American $X f$ strains, showed that a total of 26 ORFs, originally identified as unique to the North American strains also seem to be present in the citrus strains from South America [22]. Among these ORFs, 23 had been proposed to be exclusive to $X f$ strain Ann-1 and 3 were supposed to be present only in the genome of $X f$ strain Dixon. Thus, sequencing of SSH clones from citrus-associated $X f$ strains resulted in a reduction of approximately $19 \%$ in the list of unique genes that could be used as markers for North American strains (this number increases to $27.7 \%$ if we consider only the list of genes believed to be unique to $\mathrm{Xf}$ strain Ann-1) [22,36]. These findings reinforce the importance of gathering more information regarding the genomic composition of South American strains - including strains isolated from other hosts, such as coffee, to help in understanding the evolutionary history of the $X f$ group and assist in the development of tools for specific identification of pathovars [40] and other variants.

At this point, it is not clear whether the increasing overlap between elements found in South and North American strains are a result of ancestry, or represent lateral transfer events among strains [41]. Although the geographical separation of South and North American strains presents a clear barrier to lateral gene transfer events, the evolutionary history of the $X f$ genome has been shown to be extremely dynamic, highly influenced by the activity of transpositional elements from its large flexible gene pool $[26,42]$. In fact, direct evidence for the occurrence of genetic exchange between $X f$ strains from the two continents has already been reported after analysis of one $X f$ strain, obtained from plum trees in South America [43]. Regardless of its geographical origin, the genomic profile obtained for this strain clearly indicated that it descended from North American strains and was likely to have been accidentally introduced into the South American continent via infected plant material. However, this strain carried practically all genes from $\mathrm{p} X f 51$, a large plasmid 
found exclusively in South American $X f$ strains, which was likely acquired by conjugation events with South American strains [26].

Thus, given the fact that $X f$ strains are known to infect more than 100 plant species - many of which are commercial crops that are constantly shipped to foreign countries [13] (see also [44]), it is not unlikely to assume that other contamination events might have taken place, allowing the introduction of North American strains into the South American territory, and vice versa. Further conjugation events, for instance, might have introduced genes that were specific to the North American strains into the gene pool of South American strains, which could have been facilitated by the presence of such a large set of transposable elements in the $X f$ genome and the fact that multiple strains have been shown to coexist in the same host - both in the case of infected plants, as well as insect vectors $[45,46]$.

The dynamics of $X f$ genome evolution can also be deduced through evaluation of other mobile elements, particularly in the case of GI1, which seems to be absent from the North American strains, but present in one or more copy numbers in South American strains, as shown in Figure 1. Among all mobile elements identified in $X f$, GI1 is the one that best fulfills the definition of a Genomic Island, since it displays a higher GC content, altered codon bias, insertion at the 3 'end of a tRNA gene (tRNA $\mathrm{N}$ ) and the presence, at one end, of ORFs that display high similarity to a heterodimeric integrase found in association with an insertion element from Helicobacter pylori (ORFs Xf0535 and Xf0536) [47,48]. More interestingly, GI1 may be significant for the evolution of the $X f$ group, since all studies undertaken so far, involving a total of 10 different South American strains, obtained from both citrus and coffee, indicate that this element may represent a genomic sinapomorphy for the South American $X f$ strains [26]. At this point, it is not possible to determine if elements present in GI1 play any role(s) in mediating adaptation of South American Xf strains to their specific hosts, nor if they participate in the process plant infection and colonization. Nonetheless, this element carries a series of ORFs whose products are potentially involved with host adaptation and pathogenicity, resembling the structure of Pathogenicity Islands (PAIs) observed in other bacteria [49]. For instance, GI1 carries a unique fimbrillin gene, represented by ORF Xf0487. Fimbrillins are components of bacterial type I fimbriae, which are directly implicated in the process of attachment to different types of substrates and biofilm formation [50]. Novel fimbriae, composed by distinct fimbrillin genes, are believed to be important virulence determinants, allowing colonization of specific hosts and differentiation of virulent clonal groups of pathogenic bacteria, as in the case of E. coli strains, in which new fimbrillin isomorphs are also associated with horizontally transferred elements [51]. Interestingly, $X f$ strains that display specificity to different host and vector species also display a variable number of fimbrilling homologues scattered throughout their genomes $[15,18,19]$.

GI1 has also been shown to carry toxin-associated genes, such as ORF Xf0513, which encodes a hemolysin-like protein, which is implicated in cytotoxic reactions associated with many pathogenic bacteria [52], and ORF Xf 0486, involved in the synthesis of the LPS fraction of Gram-negative bacteria that mediates adverse reactions in both human and animal hosts during infection by pathogenic bacteria [53]. In the case of phytobacteria, the O-antigen portion of LPS has been shown to display a strain-specific pattern, which is believed to play a major role in host recognition during the plant colonization process [54]. Finally, GI1 also carries ORF Xf0506, which encodes the virulence-associated factor vap $\mathrm{E}$ from Dichelobacter nodosus, the causative agent of ovine footrot disease. In this bacterium, the vap genes are present in a family of Pathogenicity Islands called the Vap elements [32]. Interestingly, up to 3 different Vap elements, varying in length and ORF composition, have been mapped throughout the genome of $D$. nodosus and although their exact function(s) are still unknown, their presence has been clearly shown to be associated with the virulence phenotype in this bacterium [32]. Curiously, as mentioned above, the vapEcontaining region of GI1 is also duplicated in Xf strain $9 \mathrm{a} 5 \mathrm{c}$, as a part of GI5, resembling the organization of Vap elements in $D$. nodosus.

As mentioned above, additional virulence factors have now been identified in the genome of citrus-associated strains through the SSH experiments. One of these elements encodes a new form of pilin, associated with type IV fimbriae, whose twitching motility mechanism has been shown to be of capital importance to host colonization in $X f$ [55]. This finding reinforces the importance of fimbriae for the evolutionary divergence of $X f$ strains. Transcriptional regulators, such as the $a b r \mathrm{~B}$ activator have also been found through the SSH experiments. This transcription factor is responsible for controlling several genes, specifically activated at the end of bacterial exponential growth phase in Bacillus subtilis, and has been shown to be implicated with biofilm formation in this bacterium [56]. Interestingly, biofilm formation is believed to be an important virulence factor in $X f$ during the development of both CVC and PD, since growth in biofilm is likely to participate in the process of bacterial adherence to the xylem vessels, contribute to xylem occlusion and increase bacterial survival against the oxidative burst mediated by infected plant tissues $[57,58]$. Two different homologues of the abr $\mathrm{B}$ gene have been found in 4 
out of the 6 analyzed $X f$ strains $(56 a, 9.12 c, F b 7$ and $187 \mathrm{~b}$ ), while the new pilin gene has been found only in $X f$ strain 9.12c. Two other potential virulence factors found in the Xf-CVC gene pool seem to belong to the CysE/LacA/ LpxA/NodL family of acetyltransferases, which are characterized by multiple repeats of the sequence [LIV]-G-X(4) [59]. In both cases, the highest similarities found for these newly identified acetyltransferases are with genes $l p x \mathrm{~A}$ and $l p x \mathrm{D}$ from the North American strains Ann-1 and Temecula-1 $[18,19]$, which are involved in synthesis and modification of the O-antigen fraction of Gram-negative bacteria LPS. As mentioned above, the strain-specific structure of the $\mathrm{O}$-antigen has been show to be an important mediator in plant colonization by symbiotic bacteria, especially in the case of nodule formation during Rhizobium-legume interactions [59]. Finally, the genomes of $X f$ strains $187 \mathrm{~b}$ and $9.12 \mathrm{c}$ seem to carry a copy of the gene that encodes the Zonula Occludens Toxin (Zot), also found in $X f$ strain Ann-1. zot-like genes have been found in association with several bacterial pathogens, such as Xanthomonas, Vibrio and Stenotrophomonas, among others [60] and are likely to be laterally transferred among microorganisms through the action of filamentous phages [61]. This toxin has been originally described as an important virulence factor in Vibrio cholerae, and seems to be responsible for the development of severe cases of diarrhea caused by $V$. cholerae strains that do not carry the cholera toxin gene $c t x \mathrm{~A}$. The activity of Zot as an enterotoxin seems to be associated to its capacity to interfere with tight junctions of the gastrointestinal epithelium, altering its permeability to water and other substances $[61,62]$. Nonetheless, regardless of its recognized importance as a virulence factor in animal or human infections, there is no direct evidence that Zot plays any role(s) during plant colonization and/or pathogenicity, although this gene has also been found in the genome of Xanthomonas campestris, the causative agent of black rot disease, characterized by hyper-hydration of infected plant tissues, associated with wet edged lesions, which may be a result of Zot activity [63].

\section{Conclusion}

The experiments described in the present study represent the first attempt to conduct microarray-based genomic comparisons and a large-scale survey of genes present in the genomes of South American $X f$ strains. The results from the microarray-based comparison provide further evidence concerning the intense transpositional activity of several horizontally transferred elements and reinforce previous studies regarding the importance of lateral gene transfer as a major mediator in the evolution of this important group of phytopathogens. Moreover, comparison of the microarray-based genomic profiles showed similarity between $X f$ strains $9 \mathrm{a} 5 \mathrm{c}$ and $\mathrm{Fb} 7$, which is unexpected, given the geographical and chronological differ- ences associated with the isolation of these microorganisms. It is clear that a more comprehensive evaluation of both coffee- and Pecosita-related strains is necessary before we can fully understand the evolutionary history of South American Xf strains and their associated diseases.

The characterization of approximately 9,000 SSH clones, from six representatives of citrus haplotypes, have now provided a more comprehensive view of the size and composition of the Xf-CVC gene pool, allowing us to identify 290 new ORFs - a number that represents an 10.2\% increase in our current knowledge of the South American $X f$ gene pool. These results allowed identification of new putative virulence factors, as well as novel potential markers for strain identification within this subgroup of phytopathogens by molecular-based approaches. Moreover, several sequences previously believed to be unique markers for North American strains have now been found in the genomes of these South American strains [22]. These new data point to the necessity of revising the molecular markers currently accepted as potential targets for identification of distinct $X f$ strains in the wild [22]. Finally, by evaluating the rate at which novel sequences have been identified through the SSH approach, we conclude that the complete composition of the South American $X f$ gene pool can still be stretched, specially if this type of analysis is further extended to strains obtained from alternative hosts, such as coffee, which is known to harbor many different $X f$ strains throughout the South American territory [64].

\section{Methods}

\section{Strains, growth conditions and DNA extraction}

All $X f$ strains used in this work (Table 1) have been isolated by our research group and are deposited at the culture collection of the Centro APTA Citros Sylvio Moreira. Those interested in obtaining samples of these strains and/or more specific information should contact HDCF helvecio@centrodecitricultura.br. Four Xf strains (9.12c, 56a, 187b, and 36f) have been previously described and are representatives of the most prevalent $X f$-CVC haplotypes found out of 360 strains obtained from the northwestern, central, western, and southern regions of the State of São Paulo [28]. Xf strain Cv21 was obtained in February 2001 from a non-symptomatic sweet orange tree (C. sinensis) in the city of Colina, SP. The tree was grafted onto a Poncirus trifoliate rootstock and was present within a highly CVC-infected orchard. $X f$ strain $\mathrm{Fb} 7$ was isolated in October, 2000, from a ten-year-old sweet orange tree (C. sinensis cv. Valencia) grafted onto a Poncirus trifoliate rootstock in the province of Corrientes, Argentina. The tree had several branches carrying leaves that displayed typical Pecosita symptoms [65]. 
For strain isolation, 3-5-mm-diameter branches were collected, surface disinfected, cut in the middle and the internal ends were squeezed with a pair of pliers. The sap was blotted onto BCYE agar plates [66] and incubated at $28^{\circ} \mathrm{C}$ for 15 to 20 days. Isolated colonies were selected using a stereo-microscope, streaked onto fresh BCYE agar plates, and incubated at $28^{\circ} \mathrm{C}$ for 7 days. Identification of $X$. fastidiosa was carried out based on fastidious in vitro growth, white color of colonies, and PCR assays using primers specific to CVC-causing strains of $X$. fastidiosa [16]. All strains were have been maintained at $-80^{\circ} \mathrm{C}$. For this work, the bacteria were recovered on PW agar medium [67] and the plates maintained for 10 days at $28^{\circ} \mathrm{C}$. The colonies were transferred once to new plates containing the same medium, grown for 20 days and harvested for DNA extraction using the protocol developed by Wilson [68].

\section{Microarray fabrication}

$\mathrm{Xf}$ microarrays have been constructed as previously described $[26,30]$. Briefly, representative sequences from approximately 2200 ORFs from the $X f$ strain 9 a 5 c genome (> 90\% coverage) were PCR amplified, purified and spotted onto CMT-GAPS silane-coated slides (Corning), using an Affymetrix 427 arrayer, according to the manufacturer's instructions.

\section{DNA labeling and hybridization conditions}

Labeling reactions and purification were performed as described in Nunes and coworkers [26]. Arrays were hybridized overnight $\left(42^{\circ} \mathrm{C}\right)$ in a GeneTac Hybridization Station (Genomic Solutions, Inc - Ann Arbor, MI), in $6 \times$ SSC, $5 \times$ Denhardt's solution, $0.25 \mathrm{mg} / \mathrm{ml}$ sheared salmon sperm DNA, $0.5 \%$ SDS and $2 \mu \mathrm{g}$ of each labeled DNA sample. After hybridization, slides were washed twice $\left(42^{\circ} \mathrm{C}\right)$ in $0.5 \times \mathrm{SSC}, 0.01 \% \mathrm{SDS}$, followed by two washes in $0.06 \times$ SSC, $0.01 \%$ SDS and two final washes in $0.06 \times$ SSC. All washing steps consisted of 1 minute of flow, followed by 5 minutes of incubation. Slides were then dried and submitted to fluorescence detection.

\section{Image acquisition and analysis}

Hybridized arrays were scanned in an Affymetrix 418 Array Scanner and images were analyzed with Affymetrix Jaguar v 2.0 [69]. Quality control of the hybridized spots was automatically performed by the software, based on spot morphology and local signal-to-background ratio, using the Easy Threshold and Variable Circle Size Algorithms [69]. In all experiments, reliable hybridization signals were obtained for more than $90 \%$ of the arrayed probes (see [30]). Normalization between the intensities in the two channels was achieved with the Jaguar Control Spots option, using a list of 30 control ORFs that shared sequence identity in the genomes of $X f$ strains $9 \mathrm{a} 5 \mathrm{c}$ and Temecula-1. For each pair of strains, two independent hybridizations were performed. Since each microarray carried 2 copies of the arrayed genes, these hybridizations resulted in a total of 4 measurements for each probe in the microarray. These data were consolidated into a GATC database with Affymetrix MicroDB v.2.0 and the averages from all six readings were submitted to scatter plot visualization with Affymetrix Data Mining Tool v.2.0. Statistical validation of fold change variations was performed with the aid of the Significance Analysis of Microarrays (SAM) method proposed by Tusher and coworkers [70]. Spots that showed a Reference/Test ratio $<1: 2$ were considered to be present in greater copy number in the test over the reference strain, as proposed by Smoot and coworkers [71], while spots that showed an average Reference/Test ratio $>5: 1$ were considered to be missing in the test strain. The application of these criteria in a direct sequence comparison between $X f$ strains $9 \mathrm{a} 5 \mathrm{c}$ and Temecula- 1 , which have been completely sequenced, provided an estimated error rate below $0.3 \%$ [30]. Raw and normalized data from all microarray hybridizations, as well as the microarray complete annotation file have been submitted (in MIAME-compliant format) to NCBI's Gene Expression Omnibus (GEO) and can be assessed through Series number GSE 8493.

Genome comparisons were viewed and compared using TIGR Multi-Experiment Viewer (TMEV), v.4.0 [72]. For the visualization of comparative profiles from each analyzed strain, we applied the method proposed by Smoot and coworkers [71], where ORFs shared by the reference and each test strain were labeled 0 , while ORFs exclusive to the reference strain, or present in greater copy number in the test over the reference strain were labeled 1 and -1 , respectively.

\section{Suppressive Subtraction Hybridization}

Suppressive subtraction hybridization was performed essentially as described by Agron and coworkers [73]. Briefly, $4 \mu \mathrm{g}$ of both tester and driver DNA were individually digested with the different restriction endonucleases chosen for this study, in a $200 \mu \mathrm{L}$ reaction for approximately 16 hs. Next, the reactions were terminated by the addition of $1 \mu \mathrm{L} 0.5 \mathrm{M}$ EDTA, heated to $65^{\circ} \mathrm{C}$ for $30 \mathrm{~min}$ utes and the DNA was purified by phenol-chloroform and concentrated to $10 \mu \mathrm{L}$ dd $\mathrm{H}_{2} \mathrm{O}$, after ethanol precipitation. Two small samples of each digested tester DNA (120 ng) were ligated to their specific adaptors 1 and 2 (see [73]), in two separate ligation reactions. Each ligation was performed in a $10-\mu \mathrm{L}$ final volume, containing $1 \mu \mathrm{L}(200$ units) of T4 DNA ligase and $1 \mu \mathrm{L}$ of $10 \times$ ligation buffer (New England BioLabs), at $16^{\circ} \mathrm{C}$ for 16 hs. The first step of the subtraction hybridization was then performed, mixing $12 \mathrm{ng}$ of each adaptor-ligated tester DNA to $600 \mathrm{ng}$ of digested driver DNA, in a $5 \mu \mathrm{L}$ reaction volume, containing $250 \mathrm{mM}$ Hepes (pH8.3), $2.5 \mathrm{M} \mathrm{NaCl}, 1 \mathrm{mM}$ EDTA. These mixtures were denatured by incubation at $98^{\circ} \mathrm{C}$ for 
$1.5 \mathrm{~min}$ and transferred to $65^{\circ} \mathrm{C}$ for $1.5 \mathrm{hs}$. For the second step of the SSH reaction, the two mixtures derived from the first step were mixed and $600 \mathrm{ng}$ of digested driver DNA were added to the solution. The mixture was again denatured by incubation at $98^{\circ} \mathrm{C}$ for $1.5 \mathrm{~min}$ and incubated at $65^{\circ} \mathrm{C}$ for 14 hs. The resulting solution was diluted in $200 \mu \mathrm{L}$ of Dilution Buffer ( $50 \mathrm{mM} \mathrm{NaCl}, 5 \mathrm{mM}$ Hepes, pH 8.3, $0.2 \mathrm{mM}$ EDTA) and incubated at $65^{\circ} \mathrm{C}$ for 10 more minutes, to eliminate non-specific hybridizations. One microliter $(1 \mu \mathrm{L})$ from this final reaction was PCR amplified with the P01 initiator [73], in a $50 \mu \mathrm{L}$ reaction, using the reagents from the Advantage 2 Polymerase Mix kit (BD Biosciences), according to the manufacturer's instructions. The cycling profile for the PCR reactions included 25 cycles at: $95^{\circ} \mathrm{C}$ for 30 seconds, $66^{\circ} \mathrm{C}$ for 30 seconds and $72^{\circ} \mathrm{C}$ for $1.5 \mathrm{~min}$. The final reaction was then diluted 20 times in $10 \mathrm{mM}$ Tris $\mathrm{HCl}, \mathrm{pH} 7.5$ and a $1-\mu \mathrm{L}$ aliquot of this mixture was submitted to a second PCR reaction with initiators NP01 and NP02 (20 $\mu \mathrm{M}$ each) [73]. The reaction mixture was essentially as described above, but the cycling profile included only 10 cycles at: $95^{\circ} \mathrm{C}$ for 30 seconds, $68^{\circ} \mathrm{C}$ for 30 seconds and $72^{\circ} \mathrm{C}$ for $1.5 \mathrm{~min}$. Finally, $3-\mu \mathrm{L}$ aliquots from each $\mathrm{SSH}$ reaction were ligated to the pGEM-T vector (Promega), according to the manufacturer's instructions and this was used to transform competent $E$. coli cells, in order to generate the $\mathrm{SSH}$ libraries. Using 3 different restriction nucleases for the analysis of each strain, a total of 9,246 clones were isolated from 18 SSH libraries (Table 3).

\section{DNA sequencing and analysis}

All SSH clones were selected and submitted to automated DNA sequencing using an ABI 3100 DNA analyzer, according to the manufacturer's instructions. Further analyses were performed for each individual strain separately. Thus, sequences from each group of strain-specific SSH libraries were trimmed, in order to exclude vector sequences and poor quality regions (Phred < 20), and aligned with the aid of CAP3 [74]. Sequences that remained as singlets, or resulted in small contigs with poor quality consensus sequences (Phred < 40) were excluded from further analyses. The consensus sequences from the remaining contigs were filtered against the genome of $X f$ strain 9a5c with the aid of the software cross_match [33], allowing the identification of stretches of DNA that were exclusive to the tested strains. The cross_match parameters used to filter both vector and $X f$ strain $9 \mathrm{a} 5 \mathrm{c}$ sequences were minmatch $=15$ and minscore $=20$. These newly identified sequences were analyzed with GeneMark, [34] to search for new individual ORFs present in their structure. The sequences from all newly identified ORFs were submitted to GenBank and can be accessed through numbers ER935541 to ER935830.
Since some of these ORFs could be present in the genome of more than one tested strain, the redundancy of the dataset was reduced, submitting the predicted aminoacid sequences from all identified ORFs to a clusterization analysis with the aid of Blast_Clust [75] and ClustalW [76], using a Perl script specially developed for this purpose [77]. This allowed the distribution of the 290 ORFs originally identified by GeneMark into 135 Groups of Orthologous Elements (GOEs). Analyses of similarity against the GenBank have next been performed with Blastx, using the consensus sequences from each GOE as input, allowing the assignment of putative functions for each of these newly identified elements, as well as their distribution into the different functional categories originally described by Simpson and coworkers [15].

The rate at which novel nucleotides could be identified in the SSH clones was determined by submitting subsets of $\mathrm{SSH}$ sequences to analysis with PhedPhrap/CAP3/ cross_match (9a5c), as described above. After processing each subset, the number of novel nucleotides identified in the resulting sequence was determined by counting the nucleotides in the assembled contigs. Each sequence subset was built choosing random sequences within the whole set of $X f$ SSH sequences. A Perl script was developed for such purpose [77].

\section{Authors' contributions}

VSS and FBR carried out the microarray analyses, SSH and sequencing experiments. CSS and DCDR were responsible for sequence alignment and other bioinformatics analyses. AAS, HDCF and MAM were responsible for helping in conceiving the study, as well as $X f$ strain selection, maintenance and DNA extraction. LRN and RCO were responsible for conceiving the project, as well as most data interpretation, general coordination of the study and final manuscript elaboration. All authors read and approved the final manuscript.

\section{Additional material}

\section{Additional File 1}

List of ORFs found to be deleted or present in higher copy number in the tested strains, using as a reference, the genome of Xf strain 9a5c. http:// www.umc.br/ sshida/table absent.htm

Click here for file

[http://www.biomedcentral.com/content/supplementary/14712164-8-474-S1.PDF]

\section{Additional File 2}

Distribution and sequence of the 290 newly identified ORFs throughout the genomes of the tested Xf strains. http://www.umc.br/ shida/ table orfs.htm

Click here for file

[http://www.biomedcentral.com/content/supplementary/14712164-8-474-S2.PDF] 


\section{Additional File 3 \\ Most relevant BLAST hits found for the consensus sequences of each GOE. http://www.umc.br/ shida/blast hit table 135GOE.htm \\ Click here for file \\ [http://www.biomedcentral.com/content/supplementary/1471- 2164-8-474-S3.PDF]}

\section{Acknowledgements}

This work was supported by grants from Fundação de Amparo à Pesquisa do Estado de São Paulo - FAPESP (Processes \# 03/07553-3 and \# 04/ 08925-4) and Fundação de Amparo ao Ensino e à Pesquisa - FAEP.

\section{References}

I. Hopkins DL, Mollenhauer HH: Rickettsia-like bacterium associated with Pierce's disease of grapes. Science 1973, I 79:298-300.

2. Wells JM, Raju BC, Hung HY, Weisburg WG, Mandelco-Paul L, Brenner DJ: Xylella fastidiosa, new-genus, new-species gram negative xylem-limited fastidious plant bacteria related to Xanthomonas spp. International Journal of Systematic Bacteriology 1987, 37:|36-143.

3. Goodwin P, Purcell AH: Pierce's disease. In Grape Pest Management 2nd edition. Division of Agriculture and Natural Resources, Oakland; 1992:76-84.

4. Park YL, Perring TM, Yacoub R, Bartels DW, Elms D: Spatial and temporal dynamics of overwintering Homalodisca coagulata (Hemiptera: Cicadellidae). J Econ Entomol 2006, 99: I 936- I 942.

5. Castle SJ, Naranjo SE, Bi JL, Byrne FJ, Toscano NC: Phenology and demography of Homalodisca coagulata (Hemiptera: Cicadellidae) in southern California citrus and implications for management. Bull Entomol Res 2005, 95:621-634.

6. The Pierce's Disease Control Program California Department of Food and Agriculture [http://www.cdfa.ca.gov/phpps/pdcp/].

7. Rossetti V, Garnier M, Bové JM, Beretta MJG, Teixeira ARR, Quaggio JA, De Negri D: Occurrence of xylem-restricted bacteria in sweet orange trees affected by chlorotic variegation, a new citrus disease in Brazil. Comptes Rendus de l'Academie des Sciences Serie III 1990, 3 I 0:345-350.

8. Bové JM, Ayres AJ: Etiology of three recent diseases of citrus in Sao Paulo State: Sudden death, variegated chlorosis and huanglongbing. IUBMB Life 2007, 59:346-354.

9. Fernandes WB Jr: Analysis of the World Processed Orange Industry. In PhD thesis University of Florida; 2003.

10. FUNDECITRUS - Fund for Citrus Plant Protection [http:// www.fundecitrus.com.br/english/est cvc us.html\#cvc shist]

II. Purcell $\mathrm{AH}$, Hopkins DL: Fastidious xylem-limited bacterial plant pathogens. Ann Rev Phytopathol 1996, 34:|31-I5I.

12. Purcell AH, Saunders SR, Hendson M, Grebus ME, Henry MJ: Causal role of Xylella fastidiosa in oleander leaf scorch. Phytopatology 1999, 89:53-58.

13. Hopkins DL, Purcell AH: Xylella fastidiosa : Cause of Pierce's disease of grapevine and other emergent diseases. Plant Disease 2002, 86: $1056-1066$.

14. Doddapaneni H, Francis M, Yao J, Lin H, Civerolo EL: Genome-wide analysis of Xylella fastidiosa : implications for detection and strain relationships. Afr J Biotechnol 2007, 6:055-066.

15. Simpson AJ, Reinach FC, Arruda P, Abreu FA, Acencio M, Alvarenga R, Alves LM, Araya JE, Baia GS, Baptista CS, Barros MH, Bonaccorsi ED, Bordin S, Bove JM, Briones MR, Bueno MR, Camargo AA, Camargo LE, Carraro DM, Carrer H, Colauto NB, Colombo C, Costa FF, Costa MC, Costa-Neto CM, Coutinho LL, Cristofani M, DiasNeto E, Docena C, El-Dorry H, Facincani AP, Ferreira AJ, Ferreira VC, Ferro JA, Fraga JS, Franca SC, Franco MC, Frohme M, Furlan LR, Garnier M, Goldman GH, Goldman MH, Gomes SL, Gruber A, Ho PL, Hoheisel JD, Junqueira ML, Kemper EL, Kitajima JP, Krieger JE, Kuramae EE, Laigret F, Lambais MR, Leite LC, Lemos EG, Lemos MV, Lopes SA, Lopes CR, Machado JA, Machado MA, Madeira AM, Madeira HM, Marino CL, Marques MV, Martins EA, Martins EM, Matsukuma AY, Menck CF, Miracca EC, Miyaki CY, Monteiro-Vitorello $\mathrm{CB}$, Moon DH, Nagai MA, Nascimento AL, Netto LE, Nhani A Jr,
Nobrega FG, Nunes LR, Oliveira MA, de Oliveira MC, de Oliveira RC, Palmieri DA, Paris A, Peixoto BR, Pereira GA, Pereira HA Jr, Pesquero JB, Quaggio RB, Roberto PG, Rodrigues V, de M Rosa AJ, de Rosa VE Jr, de Sa RG, Santelli RV, Sawasaki HE, da Silva AC, da Silva AM, da Silva FR, da Silva WA Jr, da Silveira JF, Silvestri ML, Siqueira WJ, de Souza AA, de Souza AP, Terenzi MF, Truffi D, Tsai SM, Tsuhako $M H$, Vallada $H$, Van Sluys MA, Verjovski-Almeida S, Vettore $A L$, Zago MA, Zatz M, Meidanis J, Setubal JC: The genome sequence of the plant pathogen Xylella fastidiosa. Nature 2000, 406: $15 \mid-159$.

16. Pooler MR, Hartung JS: Genetic relationships among strains of Xylella fastidiosa from RAPD-PCR data. CurrMicrobiol 1995, 31:134-I37.

17. Hendson M, Purcell AH, Chen D, Smart C, Guilhabert M, Kirkpatrick $B$ : Genetic diversity of Pierce's disease strains and other pathotypes of Xylella fastidiosa. Appl Environ Microbiol 200I, 67:895-903.

18. Bhattacharyya A, Stilwagen S, Ivanova N, D'Souza M, Bernal A, Lykidis A, Kapatral V, Anderson I, Larsen N, Los T, Reznik G, Selkov E Jr, Walunas TL, Feil H, Feil WS, Purcell A, Lassez JL, Hawkins TL, Haselkorn R, Overbeek R, Predki PF, Kyrpides NC: Wholegenome comparative analysis of three phytopathogenic Xylella fastidiosa strains. Proc Natl Acad Sci USA 2002, 99:12403-I2408

19. Van Sluys MA, de Oliveira MC, Monteiro-Vitorello CB, Miyaki CY, Furlan LR, Camargo LE, da Silva AC, Moon DH, Takita MA, Lemos EG, Machado MA, Ferro MI, da Silva FR, Goldman MH, Goldman GH, Lemos MV, El-Dorry H, Tsai SM, Carrer H, Carraro DM, de Oliveira RC, Nunes LR, Siqueira WJ, Coutinho LL, Kimura ET, Ferro ES, Harakava R, Kuramae EE, Marino CL, Giglioti E, Abreu IL, Alves LM, do Amaral AM, Baia GS, Blanco SR, Brito MS, Cannavan FS, Celestino AV, da Cunha AF, Fenille RC, Ferro JA, Formighieri EF, Kishi LT, Leoni SG, Oliveira AR, Rosa VE Jr, Sassaki FT, Sena JA, de Souza AA, Truffi D, Tsukumo F, Yanai GM, Zaros LG, Civerolo EL, Simpson AJ, Almeida NF Jr, Setubal JC, Kitajima JP: Comparative analyses of the complete genome sequences of Pierce's disease and citrus variegated chlorosis strains of Xylella fastidiosa. J Bacteriol 2003, I 85:1018-1026.

20. de Souza AA, Takita MA, Coletta-Filho HD, Caldana C, Goldman GH, Yanai GM, Muto NH, de Oliveira RC, Nunes LR, Machado MA: Analysis of gene expression in two growth states of Xylella fastidiosa and its relationship with pathogenicity. Mol Plant Microbe Interact 2003, 16:867-875.

21. Reddy JD, Reddy SL, Hopkins DL, Gabriel DW: TolC is required for pathogenicity of Xylella fastidiosa in Vitis vinifera grapevines. Mol Plant Microbe Interact 2007, 20:403-4I0.

22. Doddapaneni H, Yao J, Lin H, Walker MA, Civerolo EL: Analysis of the genome-wide variations among multiple strains of the plant pathogenic bacterium Xylella fastidiosa. BMC Genomics 2006, 7:225.

23. Lin H, Civerolo EL, Hu R, Barros S, Francis M, Walker MA: Multilocus simple sequence repeat markers for differentiating strains and evaluating genetic diversity of Xylella fastidiosa. Appl Environ Microbiol 2005, 71 :4888-4892.

24. Schuenzel EL, Scally M, Stouthamer R, Nunney L: A multigene phylogenetic study of clonal diversity and divergence in North American strains of the plant pathogen Xylella fastidiosa. Appl Environ Microbiol 2005, 7 I:3832-3839.

25. Mehta A, Rosato YB: Phylogenetic relationships of Xylella fastidiosa strains from different hosts, based on I6S rDNA and I6S-23S intergenic spacer sequences. Int J Syst Evol Microbiol 200I, 5 I:3II-318.

26. Nunes LR, Rosato YB, Muto NH, Yanai GM, da Silva VS, Leite DB, Goncalves ER, de Souza AA, Coletta-Filho HD, Machado MA, Lopes SA, de Oliveira RC: Microarray analyses of Xylella fastidiosa provide evidence of coordinated transcription control of laterally transferred elements. Genome Res 2003, I3:570-578.

27. Schaad NW, Postnikova E, Lacy G, Fatmi M, Chang C): Xylella fastidiosa subspecies: $X$ fastidiosa subsp [correction] fastidiosa [correction] subsp nov, $X$ fastidiosa subsp multiplex subsp nov, and $X$ fastidiosa subsp pauca subsp nov. Syst Appl Microbiol 2004, 3:290-300.

28. Coletta-Filho HD, Machado MA: Geographical genetic structure of Xylella fastidiosa from citrus in São Paulo State, Brazil. Phytopathology 2003, 93:28-34. 
29. Dorrell N, Hinchliffe SJ, Wren BW: Comparative phylogenomics of pathogenic bacteria by microarray analysis. Curr Opin Microbiol 2005, 8:620-626.

30. Costa de Oliveira R, Yanai GM, Muto NH, Leite DB, de Souza AA Coletta-Filho HD, Machado MA, Nunes LR: Competitive hybridization on spotted microarrays as a tool to conduct comparative genomic analyses of Xylella fastidiosa strains. FEMS Microbiol Lett 2002, 2 1 6:15-21.

31. Brlansky RH, Davis CL, Timmer LW, Howd DS, Contreras J: Xylemlimited bacteria in citrus from Argentina with symptoms of citrus variegated chlorosis. (Abstr) Phytopathology 1991, 81:1210.

32. Whittle G, Bloomfield GA, Katz ME, Cheetham BF: The site-specific integration of genetic elements may modulate thermostable protease production, a virulence factor in Dichelobacter nodosus, the causative agent of ovine footrot. Microbiology 1999, I 45:2845-2855

33. CROSS_MATCH [http://www.phrap.org/phredphrap consed.html]

34. Borodovsky M, Mclninch J: GeneMark: parallel gene recognition for both DNA strands. Computers \& Chemistry 1993, 1 7:123-133.

35. Gelvin SB: Agrobacterium and plant genes involved in T-DNA transfer and integration. Annu Rev Plant Physiol Plant Mol Biol 2000, 5 I:223-256.

36. Xylella fastidiosa database [http://fresno.ars.usda.gov/citrusdis ease/CVC index.htm]

37. Davidson SK, Stahl DA: Transmission of nephridial bacteria of the earthworm Eisenia fetida. Appl Environ Microbiol 2006, 72:769-775.

38. Li W-B, Pria D, Teixeira DC Jr, Miranda VS, Ayres AJ, Franco CF, Costa MG: Coffee leaf scorch caused by a strain of Xylella fastidiosa from citrus. Plant Dis 2001, 85:501-505.

39. Paradela-Filho O, Sugimori MH, Ribeiro IJA, Garcia A Jr, Beretta MJG, Harakawa R, Machado MA, Laranjeira FF, Rodrigues Neto J, Beriam LOS: Occurrence of Xylella fastidiosa in coffee plants in Brazil. Summa Phytopathologica 1997, 23:46-49.

40. de Lima JEO, Miranda VS, Hartung JS, Brlansky RH, Coutinho A, Roberto SR, Carlos EF: Coffee leaf scorch bacterium: Axenic culture, pathogenicity, and comparison with Xylella fastidiosa of citrus. Plant Dis 1998, 2:94-97.

41. Konstantinidis KT, Tiedje JM: Genomic insights that advance the species definition for prokaryotes. Proc Natl Acad Sci USA 2005, 102:2567-2572.

42. Binnewies TT, Motro Y, Hallin PF, Lund O, Dunn D, La T, Hampson DJ, Bellgard M, Wassenaar TM, Ussery DW: Ten years of bacterial genome sequencing: comparative-genomics-based discoveries. Funct Integr Genomics 2006, 6: I65- I85.

43. French WJ, Kitajima EW: Occurrence of plum leaf scald in Brazil and Paraguay. Plant Dis Rep 1978, 62:1035-1038.

44. Host List of Pierce's Disease Strains of Xylella fastidiosa [http://www.cnr.berkeley.edu/xylella/control/hosts.htm]

45. Chen J, Groves R, Civerolo EL, Viveros M, Freeman M, Zheng Y: Two Xylella fastidiosa Genotypes Associated with Almond Leaf Scorch Disease on the Same Location in California. Phytopathology 2005, 95:708-7I4.

46. Costa HS, Guzman A, Hernandez-Martinez R, Gispert C, Cooksey DA: Detection and differentiation of Xylella fastidiosa strains acquired and retained by glassy-winged sharpshooters (Hemiptera: Cicadellidae) using a mixture of strain-specific primer sets. J Econ Entomol 2006, 99:1058-1064.

47. Karlin S: Detecting anomalous gene clusters and pathogenicity islands in diverse bacterial genomes. Trends Microbiol 200I, 9:335-343.

48. Kersulyte D, Mukhopadhyay AK, Shirai M, Berg DE: Functional organization and insertion specificity of IS607, a chimeric element of Helicobacter pylori. JBacteriol 2000, I 82:5300-5308.

49. Gal-Mor O, Finlay BB: Pathogenicity islands: a molecular toolbox for bacterial virulence. Cell Microbiol 2006, 8: 1707-1719.

50. Caiazza NC, Merritt JH, Brothers KM, O'Toole GA: Inverse regulation of biofilm formation and swarming motility by Pseudomonas aeruginosa PAI4. I Bacteriol 2007, I 89:3603-36I2.

51. Weissman SJ, Chattopadhyay S, Aprikian P, Obata-Yasuoka M, Yarova-Yarovaya Y, Stapleton A, Ba-Thein W, Dykhuizen D, Johnson JR, Sokurenko EV: Clonal analysis reveals high rate of structural mutations in fimbrial adhesins of extraintestinal pathogenic Escherichia coli. Mol Microbiol 2006, 59:975-988.
52. Russo TA, Wang Z, Davidson BA, Genagon SA, Beanan JM, Olson R, Holm BA, Knight PR 3rd, Chess PR, Notter RH: Surfactant dysfunction and lung injury due to the $E$ coli virulence factor hemolysin in a rat pneumonia model. Am J Physiol Lung Cell Mol Physiol 2007, 292:L632-643.

53. Vuorio R, Harkonen $T$, Tolvanen $M$, Vaara M: The novel hexapeptide motif found in the acyltransferases LpxA and LpxD of lipid A biosynthesis is conserved in various bacteria. FEBS Lett 1994, 337:289-292

54. Kannenberg EL, Carlson RW: Lipid A and O-chain modifications cause Rhizobium lipopolysaccharides to become hydrophobic during bacteroid development. Mol Microbiol 200I, 39:379-391

55. Meng Y, Li Y, Galvani CD, Hao G, Turner JN, Burr TJ, Hoch HC: Upstream migration of Xylella fastidiosa via pilus-driven twitching motility. J Bacteriol 2005, I 87:5560-5567.

56. Bobay BG, Benson L, Naylor S, Feeney B, Clark AC, Goshe MB, Strauch MA, Thompson R, Cavanagh J: Evaluation of the DNA binding tendencies of the transition state regulator AbrB. Biochemistry 2004, 43:16106-16118.

57. Hamon MA, Stanley NR, Britton RA, Grossman AD, Lazazzera BA: Identification of AbrB-regulated genes involved in biofilm formation by Bacillus subtilis. Mol Microbiol 2004, 52:847-860.

58. Bi JL, Dumenyo CK, Hernandez-Martinez R, Cooksey DA, Toscano NC: Effect of Host Plant Xylem Fluid on Growth, Aggregation, and Attachment of Xylella fastidiosa. J Chem Ecol 2007, 33:493-500.

59. Lerouge I, Verreth C, Michiels J, Carlson RW, Datta A, Gao MY Vanderleyden J: Three genes encoding for putative methyland acetyltransferases map adjacent to the wzm and wzt genes and are essential for $\mathbf{O}$-antigen biosynthesis in $\mathbf{R h i z o -}$ bium etli CE3. Mol Plant Microbe Interact 2003, 16:1085-1093.

60. Fasano A, Baudry B, Pumplin DW, Wasserman SS, Tall BD, Ketley JM, Kaper JB: Vibrio cholerae produces a second enterotoxin, which affects intestinal tight junctions. Proc Natl Acad Sci USA 1991, 88:5242-5246.

61. Hagemann M, Hasse D, Berg G: Detection of a Phage Genome Carrying a Zonula Occludens like Toxin Gene (zot) in clinical strains of Stenotrophomonas maltophilia. Arch Microbiol 2006, I 85:449-458.

62. Begum K, Ahsan CR, Ansaruzzaman M, Dutta DK, Ahmad QS, Talukder KA: Toxin(s), other than cholera toxin, produced by environmental non OI non OI 39 Vibrio cholerae. Cell Mol Immunol 2006, 3: II5-121.

63. Nembaware V, Seoighe C, Sayed M, Gehring C: A plant natriuretic peptide like gene in the bacterial pathogen Xanthomonas axonopodis may induce hyper - hydratation in the plant host: a hypothesis of molecular mimicry. BMC Evol Biol 2004, 24:4- I0.

64. Lopes SA, Marcussi S, Torres SCZ, Souza V, Fagan C, França SC, Fernandes NG, Lopes JRS: Weeds as alternative hosts of the citrus, coffee, and plum strains of Xylella fastidiosa in Brazil. Plant Dis 2003, 87:544-549.

65. de Coll OR, Remes-Lenicov AMM, Agostini JP, Paradell S: Detection of Xylella fastidiosa in weeds and sharpshooters in orange groves affected with citrus variegated chlorosis in Misiones, Argentine. Proccedings of 14 th Conference IOCV, Riverside 2000:216-222

66. Wells JM, Raju BC, Nyland G, Lowe SK: Medium for Isolation and Growth of Bacteria Associated with Plum Leaf Scald and Phony Peach Diseases. Appl Environ Microbiol I98I, 42:357-363.

67. Davis MJ, French W], Schaad NW: Axenic culture of the bacteria associated with phony disease of peach and plum leaf scald. Curr Microbiol I98I, 6:309-3।4.

68. Wilson K: Preparation of genomic DNA from bacteria. In Current protocols in molecular biology Edited by: Ausubel M, Brent R, Kingston RE, Moore DD, Sudman JG, Smith JA, Struhl K. New York: Greene Publishing Associates and Wiley Interscience; 1987:24 I-242.

69. Affymetrix, Inc.: Jaguar ${ }^{\mathrm{TM}}$ Software User's Guide. Version 2.0. California 2001 .

70. Tusher VG, Tibshirani R, Chu G: Significance analysis of microarrays applied to the ionizing radiation response. Proc Nat Acad Sci USA 2001, 98:5116-5121.

7I. Smoot JC, Barbian KD, Van Gompel J], Smoot LM, Chaussee MS, Sylva GL, Sturdevant DE, Ricklefs SM, Porcella SF, Parkins LD, Beres SB, Campbell DS, Smith TM, Zhang Q, Kapur V, Daly JA, Veasy LG, Musser JM: Genome sequence and comparative microarray 
analysis of serotype MI 8 group A Streptococcus strains associated with acute rheumatic fever outbreaks. Proc Natl Acad Sci USA 2002, 99:4668-4673.

72. Saeed Al, Bhagabati NK, Braisted JC, Liang W, Sharov V, Howe EA, Li J, Thiagarajan M, White JA, Quackenbush J: TM4 microarray software suite. Methods Enzymol 2006, 4I I:I34-193.

73. Agron PG, Macht M, Radnedge L, Skowronski EW, Miller W Andersen GL: Use of subtractive hybridization for comprehensive surveys of prokaryotic genome differences. FEMS Microbiol Lett 2002, 21 I: 175-182.

74. Huang $X$, Madan A: CAP3: A DNA sequence assembly program. Genome Res 1999, 9:868-877.

75. Blast_Clust [http://www.cmbi.ru.nl/bioasp courses/
a SRS BLAST CLUSTAL]

76. ClustalW [http://www.ebi.ac.uk/clustalw/]

77. Claudio S: Shida's homepage, providing access to the Perl scripts developed in this study for the cumulative analysis of novel sequences and ORFs clusterization [http://www.umc.br/ shida].

Publish with Bio Med Central and every scientist can read your work free of charge

"BioMed Central will be the most significant development for disseminating the results of biomedical research in our lifetime. "

Sir Paul Nurse, Cancer Research UK

Your research papers will be:

- available free of charge to the entire biomedical community

- peer reviewed and published immediately upon acceptance

- cited in PubMed and archived on PubMed Central

- yours - you keep the copyright

Submit your manuscript here:

http://www.biomedcentral.com/info/publishing_adv.asp
BioMedcentral 